\title{
PERSEPSI MASYARAKAT TERHADAP POTENSI EKOWISATA DI DESA SEDAHAN JAYA KECAMATAN SUKADANA KABUPATEN KAYONG UTARA
}

\author{
(Perception of Society Against The Potential of Ecotourism in Sedahan Jaya Village Subdistrict
} Sukadana Kayong Utara Regency)

\author{
Sri Purnama, Iskandar AM, M. Dirhamsyah \\ Fakultas Kehutanan Universitas Tanjungpura. Jalan Imam Bonjol Pontianak 78124 \\ Email : sripurnama.kodil@gmail.com
}

\begin{abstract}
In the middle of rate deforestation, The ecotourism appears as one of alternative economic opportunities for communities around the forest. Sedahan Jaya village is one of the villages in Kayong Utara Regency that has an excellent natural potentials, such as panoramic landscapes, as well as the region's forests and mountains. However, the utilization of natural resources in the village has not been optimally realized. Based on this condition, needed to do research about the perception of Society Against the potential of Ecotourism in Sedahan Jaya to know the level of participation and support from the local community. This research uses descriptive survey method that is with interview techniques and tools in the form of a detailed questionnaire form with the number of samples as much as 87 KK. Sampling purposive sampling done by the respondent. The results showed that people in the village of sedahan jaya have a very positive perception against the potential of ecotourism in Sedahan Jaya village following its development. This is because most of the people in the village of sedahan jaya has felt the positive impact of this ecotourism activities to their lives, both in terms of the economy as well as socio-cultural area.
\end{abstract}

Keywords : ecotoutism, public perception, Sedahan Jaya.

\section{PENDAHULUAN}

Keberadaan hutan sebagai bagian dari sebuah ekosistem yang besar memiliki arti dan peran penting dalam menyangga sistem kehidupan. Potensi sumberdaya alam hayati dan ekosistem tersebut perlu dikembangkan dan dimanfaatkan untuk kepentingan dan kesejahteraan masyarakat tanpa melupakan upaya konservasi sehingga tetap tercapai keseimbangan antara perlindungan, pengawetan dan pemanfaatan yang lestari. Potensi jasa lingkungan hutan baik langsung ataupun tidak langsung dapat dimanfaatkan secara terukur dan tidak terukur oleh manusia antara lain untuk : wisata alam, pemanfaatan sumberdaya air, supply oksigen, perlindungan sistem hidrologis dan carbon offset (Widarti, 2003).

Desa Sedahan Jaya adalah salah satu desa yang terdapat di Kecamatan Sukadana Kabupaten Kayong Utara. Desa ini memiliki potensi alam yang sangat baik, seperti panorama pemandangan alam, hamparan persawahan masyarakat yang begitu luas, serta kawasan hutan dan pegunungan yang masih alami. Namun pemanfaatan sumber daya alam yang ada di desa ini belum terealisasi secara optimal. Hal ini tampak dari minimnya 
pengelolaan sarana dan prasarana di desa tersebut, serta kurangnya pemberdayaan masyarakat setempat sebagai pihak yang seharusnya berperan aktif. Berdasarkan kondisi ini maka perlu kiranya dilakukan penelitian mengenai Persepsi Masyarakat Terhadap Potensi Ekowisata di Desa Sedahan Jaya Kecamatan Sukadana Kabupaten Kayong Utara, untuk mengetahui tingkat partisipasi dan dukungan dari masyarakat setempat.

\section{METODE PENELITIAN}

Penelitian ini dilaksanakan di desa Sedahan Jaya kecamatan Sukadana kabupaten Kayong Utara, dimana objek penelitian ini adalah masyarakat yang berdomisili di desa Sedahan Jaya. Alatalat yang digunakan didalam penelitian ini, yaitu : kamera, ATK, kuisioner, tape recorder.

Penelitian ini menggunakan metode survey yang bersifat deskriptif dengan teknik wawancara dan alat bantu kuisioner berupa formulir dengan jumlah sampel sebanyak 87 KK. Pengambilan sampel responden dilakukan dengan purposive sampling dengan karakteristik responden sebagai berikut : kepala keluarga, berdomisili di desa setempat, lama menetap minimal sudah 5 tahun, umur minimal 20 tahun (sudah berkeluarga), bisa membaca dan menulis, dan sehat jasmani dan rohani.

\section{Teknik Pengumpulan Data}

Teknik pengumpulan data dilakukan dengan teknik wawancara langsung dibantu dengan alat berupa kuisioner yang berisikan rangkaian pertanyaan mengenai sesuatu hal terkait persepsi masyarakat terhadap kegiatan ekowisata di desa Sedahan Jaya kecamatan Sukadana kabupaten Kayong Utara.

\section{Definisi Operasional}

Variabel Terikat

Variabel terikat didalam penelitian ini adalah persepsi masyarakat mengenai konsep ekowisata, serta peluang pengembangan ekowisata di Desa Sedahan Jaya.

\section{Variabel Bebas}

Variabel bebas dalam penelitian ini mencakup : tingkat pengetahuan masyarakat mengenai ekowisata, serta kosmopolitan masyarakat untuk menerima informasi mengenai persepsi masyarakat terhadap kegiatan ekowisata di desa Sedahan Jaya.

\section{Uji Kuisioner}

\section{Uji Validitas}

Teknik yang digunakan untuk mengetahui kesesuaian instrumen adalah teknik korelasi product moment yang dikemukakan oleh pearson (Arikunto, 1993). Uji terhadap kuisioner untuk penelitian menggunakan rumus korelasi product moment dengan skala angka kasar, sedangkan nilai antara skor setiap belahan tes akan dicari dengan menggunakan rumus korelasi product moment yaitu sebagai berikut :

$r_{x y}=\frac{\mathrm{N}(\Sigma \mathrm{xy})-(\Sigma \mathrm{x} \cdot \Sigma \mathrm{y})}{\sqrt{\left\{\mathrm{N} \Sigma \mathrm{x}^{2}-\left(\Sigma \mathrm{x}^{2}\right)\right\}\left\{\mathrm{N} \Sigma \mathrm{y}^{2}-\left(\Sigma \mathrm{y}^{2}\right)\right\}}}$

Dimana :

$\mathrm{N}=$ Jumlah responden

$\mathrm{X}=$ Skor pertanyaan bilangan genap

$\mathrm{Y}=$ Skor pertanyaan bilangan ganjil 
$r_{x y}=$ Koefisien korelasi

Berdasarkan rumus korelasi product moment taraf signifikan yang akan digunakan dalam hal ini adalah $5 \%$, maka alat penelitian dinyatakan valid.

\section{Uji Reliabilitas}

Rumus yang dipakai untuk menguji reliabilitas kuisioner yang digunakan adalah rumus Sperman-Brown (Arikunto, 1989), yaitu sebagai berikut :

$$
r_{1}=\frac{2 \cdot r b}{(1+r b)}
$$

Dimana :

$\mathrm{rb}=$ Korelasi product moment antara skor-skor setiap belahan

$\mathrm{r}_{1}=$ Koefisien reliabilitas

Nilai koefisien reliabilitas dapat dicari dengan menggunakan rumus korelasi product moment pada taraf signifikan yang digunakan, yaitu 5\%.

\section{Hasil Uji Kuisioner}

Jumlah responden yang diambil untuk uji kuisioner adalah sebanyak 15 KK dimana dari hasil perhitungan di peroleh nilai uji validitas sebesar 0,7398 dan nilai uji reliabilitas sebesar 0,8505 yang kemudian dibandingkan nilai tabel product moment 5\% = 0,541 dimana diperoleh hasil bahwa nilai uji validitas dan reliabilitasnya lebih besar daripada nilai tabel product moment 5\%, artinya kuisioner valid.

\section{Teknik Pengolahan Data}

\section{Menentukan dan Menilai Kriteria Faktor Persepsi}

Data jawaban dari responden yang diperoleh dari penelitian ini adalah berupa data kualitatif, maka untuk itu terlebih dahulu harus di ubah menjadi data kuantitatif, dimana untuk mengukurnya digunakan Skala Likert, dalam Skala Likert (Sumated Ratings Methode) terdapat pertanyaanpertanyaan, sehingga dalam menanggapi hal tersebut subjek memilih salah satu dari lima alternatif jawaban yang sesuai dengan keinginan subjek. Pertanyaan yang bersifat positif diberi skor $\mathrm{a}=5, \mathrm{~b}=4, \mathrm{c}=3, \mathrm{~d}=2, \mathrm{e}=1$, sedangkan pertanyaan yang bersifat negatif diberi skor kebalikannya, kemudian skor-skor yang diperoleh tersebut dijumlahkan per variabel dan diambil rata-ratanya dengan ketentuan sebagai berikut :

1. Kategori negatif dengan skor $<2,5$

2. Netral dengan skor 2,5-3,5

3. Kategori positif dengan skor $>3,5$

Sistem penilaian ini sesuai dengan Skala Likert. Untuk data yang merupakan data kuantitatif akan ditabulasikan sebagai mestinya.

\section{Teknik Pengujian Hipotesis}

Persepsi Masyarakat terhadap Kegiatan Ekowisata di desa Sedahan Jaya kecamatan Sukadana kabupaten Kayong Utara, diberlakukan pengujian hipotesis dengan menggunakan rumus Chi-kuadrat.

Rumus lengkap Chi-kuadrat $\left(\mathrm{X}^{2}\right)$ adalah :

$$
\sum \frac{\left\{\left(f_{o}-f_{t}\right)\right\}}{f t}
$$

Dimana :

$\mathrm{X}^{2}=$ Chi-kuadrat

$F o=$ Frekuensi yang diperoleh 
$F t=$ Frekuensi yang diharapkan

Frekuensi yang diharapkan (ft) pada hipotesis deskriptif dicari menggunakan cara :

$$
f t=\frac{\sum N}{\sum K}
$$

Dimana :

$f t=$ Frekuensi yang Diharapkan

$\Sigma \mathrm{N}=$ Jumlah Sampel

$\Sigma \mathrm{K}=$ Jumlah Kategori

Hubungan antara variabel terikat (persepsi masyarakat terhadap potensi ekowisata di desa Sedahan Jaya kecamatan Sukadana kabupaten Kayong Utara) dengan variabel bebas (pengetahuan dan tingkat kosmopolitan) pengujiannya menggunakan teknik statistik Chi-kuadrat. Rumus lengkap untuk Chi-kuadrat $\left(\mathrm{X}^{2}\right)$ adalah sebagai berikut :

$$
X^{2}=\Sigma \frac{\{(f o-f t)\}}{f t}
$$

Dimana :

$\mathrm{X}^{2}=$ Chi-kuadrat

$f_{0}=$ Frekuensi yang diperoleh

$f_{t}=$ Frekuensi yang diharapkan

Frekuensi yang diharapkan ( $f t)$

menurut Sumanto (1995) dalam

Purwanto (2004) adalah :

$$
f t=\frac{(\text { bixki) }}{N}
$$

Dimana :

$f_{t}=$ Frekuensi yang diharapkan

bi $=$ Jumlah baris

$\mathrm{ki}=$ Jumlah kolom

$\mathrm{N}=$ Total sampel
Keeratan hubungan antar faktor pengetahuan dan komopolitan masyarakat dengan persepsi masyarakat terhadap potensi ekowisata di desa Sedahan Jaya kecamatan Sukadana kabupaten Kayong Utara dapat diketahui dengan mengunakan rumus koefisien kontigensi (Sugiyono,2010).

$$
\mathrm{C}=\sqrt{X^{2}} / \mathrm{X}^{2}+\mathrm{n}
$$

Dimana :

$$
\begin{aligned}
& \mathrm{C}=\text { Koefisien kontignensi } \\
& \mathrm{X}^{2}=\text { Chi-kuadrat } \\
& \mathrm{n}=\text { Jumlah sampel (responden) }
\end{aligned}
$$

Dengan kriteria korelasi sebagai berikut (Sarwono,2006) :

- 0 : Tidak ada korelasi antara dua variabel

- >0 -0,25: Korelasi sangat lemah

- >0,25-0,5 : Korelasi cukup

- >0,5- 0,75 : Korelasi kuat

- >0,75-0,99 : Korelasi sangat kuat

- 1 : Korelasi sempurna

\section{HASIL DAN PEMBAHASAN}

Persepsi Masyarakat Terhadap Potensi Ekowisata di Desa Sedahan Jaya

Berdasarkan hasil perhitungan Chi Kuadrat diperoleh nilai sebesar 72,57 dan nilai tabel pada taraf signifikan $(0,05)$ sebesar 5,591. Karena nilai $\boldsymbol{\chi}^{2}$ hitung $>$ dari nilai $\boldsymbol{\chi}_{\text {tabel }}(0,05)$ maka hipotesis deskriftif diterima. Hal ini menunjukkan bahwa persepsi masyarakat terhadap potensi ekowisata di desa Sedahan Jaya cenderung berbeda.

Hubungan Tingkat Pengetahuan dengan Persepsi Masyarakat terhadap Potensi Ekowisata di Desa Sedahan Jaya 


\begin{abstract}
Hubungan antara tingkat pengetahuan dengan persepsi masyarakat terhadap potensi ekowisata di desa Sedahan Jaya berdasarkan hasil analisa data yang diperoleh $\chi^{2}$ hitung sebesar 33,8423 sedangkan $\chi^{2}$ tabel pada taraf signifikan 5\% sebesar 9,488. Dengan demikian $\chi^{2}$ hitung > dari $\chi^{2}$,yang menunjukan hubungan yang signifikan antara tingkat pengetahuan dan persepsi masyarakat terhadap potensi ekowisata di desa Sedahan Jaya, sehingga hipotesis yang menyatakan terdapat hubungan antara tingkat pengetahuan masyarakat terhadap potensi ekowisata di desa Sedahan Jaya dapat diterima. keeratan hubungan antara faktor pengetahuan dengan persepsi masyarakat dapat dilihat dari hasil perhitungan uji kontingensi, yaitu $\mathrm{C}$ maks $=0,695$. Berdasarkan kriteria korelasi (Sarwono,2006), hasil dari C maks menunjukan hubungan korelasi yang kuat $(>0,5-0,75)$ antara persepsi masyarakat dengan tingkat pengetahuan masyarakat.
\end{abstract}

\section{Hubungan Tingkat Kosmopolitan dengan Persepsi Masyarakat terhadap Potensi Ekowisata di Desa Sedahan Jaya}

Hubungan antara tingkat kosmopolitan dengan persepsi masyarakat terhadap potensi ekowisata di desa Sedahan Jaya berdasarkan hasil analisa data yang diperoleh $\chi^{2}$ hitung sebesar 34,9932 sedangkan $\chi^{2}$ pada taraf signifikan 5\% sebesar 9,488. Dengan demikian $\chi^{2}$ hitung $>$ dari $\chi^{2}$. Ini menyatakan bahwa terdapat hubungan yang signifikan antara tingkat kosmopolitan dan persepsi masyarakat terhadap potensi ekowisata di desa Sedahan Jaya sehinga hipotesis yang menyatakan terdapat hubungan antara tingkat kosmopolitan masyarakat terhadap potensi ekowisata di Sedahan Jaya dapat diterima. Keeratan hubungan antara faktor kosmopolitan dengan persepsi masyarakat dapat dilihat dari hasil perhitungan uji kontingensi, yaitu Cmaks $=0,705$. Berdasarkan kriteria korelasi (Sarwono,2006), hasil dari C maks menunjukan hubungan korelasi yang kuat $(>0,5-0,75)$ antara Persepsi masyarakat dengan Tingkat Kosmopolitan.

\section{Potensi Objek Daya Tarik Wisata Budaya}

Masyarakat desa Sedahan Jaya terdiri dari berbagai macam suku, diantaranya suku melayu, suku dayak, suku bali, suku dan suku jawa atau bisa juga disebut dengan masyarakat multikultural. Keberagaman budaya dan kesenian ini menjadi salah satu objek daya tarik wisata yang ada di Desa Sedahan Jaya.

\section{Air Terjun Lubuk Baji}

Air terjun Lubuk Baji merupakan objek wisata unggulan dari desa Sedahan Jaya. Air terjun dengan tinggi kurang lebih 8 meter ini memiliki pesona yang sangat menarik. Berdasarkan potensi yang ada di sekitar lokasi objek daya tarik wisata Lubuk Baji dan sekitarnya, berbagai atraksi yang dapat dilakukan diantaranya: wisata biodiversity berupa observasi berbagai jenis fauna, terutama Orang utan, Kelasi, dan Klempiau. Treking sambil menikmati pemandangan 
ekosistem asli hutan pegunungan di Kalimantan dan air terjun. Selain air terjun lubuk baji terdapat juga tempat pemandian yang juga merupakan salah satu objek daya tarik wisata dari desa Sedahan Jaya, diantaranya Batu Pahat dan Lubuk Bengkek.

\section{Batu Bulan}

Batu Bulan adalah salah satu objek daya tarik wisata yang cukup banyak dikunjungi di desa Sedahan Jaya. Dengan ketinggian kurang lebih 546 mdpl di batu bulan, pengunjung bisa melihat pemandangan alam serta hamparan persawahan yang ada di desa Sedahan Jaya dan sekitarnya.

\section{Bendungan di Sekitar Homestay Dusun Begasing}

Homestay di dusun Begasing merupakan sebuah penginapan untuk para tamu yang ingin menginap di desa Sedahan Jaya. Homestay yang berhadapan langsung dengan bendungan air ini menghadirkan nuansa yang sejuk dan nyaman, di dukung dengan pemandangan alam yang hijau disekitarnya homestay ini memiliki objek daya tarik sendiri bagi wisatawan yang datang ke desa Sedahan Jaya.

\section{Wisata Biodiversitas}

Selain keindahan Alam serta budayanya, desa Sedahan Jaya yang tercatat masuk kedalam kawasan Taman Nasional Gunung Palung memiliki keanekaragaman hayati yang cukup lengkap dan terkenal sampai keberbagai belahan dunia. Dengan melakukan treking si sekitar kawasan Lubuk Baji wisatawan bisa menikmati secara langsung keindahan hutan tropis yang di dukung dengan keanekaragaman hayati yang cukup bervariasi. Jenis flora yang mendominasi dikawasan ini adalah dari Famili Dipterocarpaceae, seperti contohnya Meranti Kuning, sedangkan untuk jenis flora yang menjadi objek daya tarik wisata di kawasan ini merupakan flora jenis Primata, Seperti Monyet ekor panjang (Macaca fascicularis), dan Orangutan (Pongo pygmaeus).

\section{Kesimpulan}

Hasil penelitian menunjukkan bahwa:

1. Masyarakat di desa Sedahan Jaya memiliki persepsi yang sangat positif terhadap potensi ekowisata di desa Sedahan Jaya berikut pengembangannya. Hal ini dikarenakan sebagian besar masyarakat di desa Sedahan Jaya telah merasakan dampak yang positif dari kegiatan ekowisata ini bagi kehidupan mereka, baik dari segi perekonomian maupun sosial-budaya setempat.

2. Semakin tinggi pengetahuan dan tingkat kosmopolitan seseorang maka semakin tinggi pula tingkat persepsinya, hal ini juga di pengaruhi oleh jenis pekerjaan, umur, serta pendidikan dari responden.

3. Responden dikelompokkan menjadi tiga kelompok umur, yaitu Usia Muda (15-34 Tahun),Usia Dewasa (35-54 Tahun) dan Usia Lanjut (5564 Tahun). Banyaknya jumlah responden secara keseluruhan adalah 72 responden, 41 diantaranya tergolong kedalam Usia Muda, 
dimana pada usia tersebut responden termasuk kedalam angkatan kerja produktif, sehingga kegiatan ekowisata bisa dengan mudah diterima di masyarakat.

4. Tingkat pengetahuan tenyata tidak berpengaruh terhadap persepsi masyarakat terhadap ekowisata, karena dari tingkat pendidikan yang bervariasi dari SD,SMP,SMA, dan Perguruan Tinggi ternyata pengetahuan mengenai ekowisata setempat hampir seragam, karena hampir seluruh masyarakat ikut terlibat dalam pengembangan ekowisata setempat.

5. Sebagian responden dari penelitian ini adalah petani, dan kebanyakan dari mereka juga merangkap sebagai pengurus ekowisata setempat, sehingga cenderung memiliki persepsi yang positif mengenai pengembangan ekowisata di desa Sedahan Jaya.

\section{Saran}

1. Perlu dilakukannya penyuluhan secara menyeluruh terhadap seluruh lapisan masyarakat terkait pengembangan dan pengelolaan ekowisata dalam rangka meningkatkan pengetahuan dan pertisipasi masyarakat dalam pengelolaan ekowisata itu sendiri.

2. Perlu adanya peran yang lebih intensif dari pihak pemerintah dan stakeholder terkait dalam rangka pendampingan dalam kegiatan pengelolaan dan pengembangan ekowisata di desa Sedahan Jaya.
3. Perlu adanya perbaikan infrastruktur, terutama di dusun Begasing untuk mempermudah aksesibilitas menuju destinasi wisata.

4. Perlu adanya perbaikan manajemen pengelolaan dengan melibatkan semua stakeholder yang ada di di desa Sedahan Jaya, meliputi pihak pemerintah, Taman Nasional, LSM, NGO, serta masyarakat setempat.

5. Peningkatan nilai edukasi bagi masyarakat setempat terkait materi pendukung maupun bahasa dari stakeholder terkait.

\section{DAFTAR PUSTAKA}

Achmadi, Abu Dkk. 2002. Metodologi Penelitian. Jakarta. Bumi Aksara.

Balai Taman Nasional Gunung Palung. 2010. Renstra Btngp 2010-2014. BTNGP, Kayong Utara.

Badan Pusat Statistik Kabupaten Kayong Utara. 2014. Kecamatan Sukadana Dalam Angka 2014. Bps Sukadana

Basuki, Sulistyo. 2006. Metode Penelitian. Jakarta. Wedatama Widya Sastra.

Dananjaja, 2012. Metodologi Penelitian Sosial. Yogyakarta. Graha Ilmu

Satoto, Soediro. 2012. Metode Penelitian Sastra. Surakarta.Yuma Pustaka.

Sofyan, Deni Dkk. 2013. Developing Sustainable Tourism Module. Canopy Indonesia, Pontianak.

Yoeti, Oka A. 2000. Ekowisata Pariwisata Berwawasan Lingkungan Hidup. Jakarta. P.t. Pertja. 
JURNAL HUTAN LESTARI (2019)

Vol. 7 (1) : 248 - 255

Purwanto, Y. 2004. Sikap Masyarakat Desa Kekadas dan Desa Pandan Sembut Terhadap di Berlakukannya Surat Keputusan Pemerintah Tentang Kawasan Hutan Lindung Gunung Semaung-Sepapan di Kecamatan Tayan Hulu Kabupaten Sanggau (Skripsi). Fakultas Kehutanan, Universitas Tanjungpura. Pontianak.

Sugiyono. 2011. Metode Penelitian Kombinasi (Mixed Methods). Bandung. Alvabeta.

Jonathan, Sarwono. 2006. Metode Penelitian Kuantitatif dan Kualitatif. Yogyakarta. Graha Ilmu.

Arikunto, S. 1993. Prosedur Penelitian; Suatu Pendekatan Praktik. Jakarta. Rineka Cipta.

Arikunto, S. 1989. Manajemen Penelitian. Jakarta. Rineka Cipta. 